\title{
Assessment of the Cytotoxicity of Melia azedarach $L$. Extracts on Human Adipose-derived Mesenchymal Stem Cells
}

\author{
Melia azedarach L. Özütlerinin İnsan Adipoz Kaynakı Mezenkimal \\ Kök Hücreleri Üzerindeki Sitotoksisitesinin Değerlendirilmesi
}

\author{
Research Article \\ Burcu Efe, Yusuf Furkan Galata, Yavuz Emre Arslan* \\ Regenerative Biomaterials Lab., Dept. of Bioengineering, Eng. Faculty, Çanakkale Onsekiz Mart University, Canakkale, Turkey.
}

\section{A B S TR AC T}

\begin{abstract}
$\mathrm{n}$ this study, aqueous extracts of Melia azedarach L. green fruit and leaves were obtained using two different extraction methods. The extraction yields of the green fruit and leaves were found as $24.11 \%$ and $37.98 \%$ for the infusion method; $17.76 \%$ and $27.00 \%$ for the rotating method, respectively. The total phenolic content, related to the infusion method, was ascertained for green fruit extract 173.67 $10.84 \mathrm{mg}$ Gallic Acid Equivalent $(\mathrm{GAE}) / \mathrm{g}$ dry weight and leaf extract $312.33 \pm 9.81 \mathrm{mg} \mathrm{GAE} / \mathrm{g}$ dry weight. In other respects, antioxidant activity related to the infusion method was determined for green fruit extract $172.51 \pm 13.23 \mathrm{mg}$ Trolox/L and leaf extract $569.16 \pm 10.41 \mathrm{mg}$ Trolox/L. Gas chromatography-mass spectrometry (GC-MS) analysis was performed to identify the chemical composition of the extracts. The cytotoxicity levels of the extracts were assessed on human adipose-derived mesenchymal stem cells (hAMSCS) using commercially available XTT assay. Consequently, it has been found that the green fruit extract has more cytotoxic activity than the leaf extract on hAMSCS.
\end{abstract}

\section{Key Words}

Melia azedarach L., total phenolic compounds, cytotoxicity, human adipose-derived mesenchymal stem cells.

\section{öz}

u çalışmada, Melia azedarach L. yeşil meyve ve yapraklarının sulu özleri iki farklı özütleme yöntemi kullanılarak elde edildi. Yeşil meyve ve yaprakların özütleme verimleri sırasıyla, demleme yöntemi için \%24.11 ve \%37.98; çalkalama yöntemi için ise \%17.76 ve \%27.00 olarak bulundu. Demleme yöntemi ile ilgili toplam fenolik içerik, yeşil meyve özü için $173.67 \pm 10.84 \mathrm{mg}$ galik asit eşdeğeri (GAE)/g kuru ağırlık ve yaprak özü için $312.33 \pm 9.81 \mathrm{mg} \mathrm{GAE} / \mathrm{g}$ kuru ağırlık cinsinden tespit edildi. Diğer yandan demleme yönteminde, yeşil meyve özü için $172.51 \pm 13.23 \mathrm{mg}$ Trolox/L ve yaprak özü için ise $569.16 \pm 10.41 \mathrm{mg}$ Trolox/L cinsinden antioksidan aktivite belirlendi. Özütlerin kimyasal bileşimini tanımlamak için gaz kromatografisi-kütle spektrometresi (GC-MS) analizi yapıldı. Özütlerin insan adipoz kaynaklı mezenkimal kök hücreleri (iAMKH'leri) üzerindeki sitotoksisite seviyeleri ticari olarak mevcut olan XTT testi ile değerlendirildi. Sonuç olarak, yeşil meyve özütünün iAMKH'leri üzerine yaprak özütünden daha fazla sitotoksik aktiviteye sahip olduğu bulunmuştur

\section{Anahtar Kelimeler}

Melia azedarach L., toplam fenolik bileşikler, sitotoksisite, insan adipoz kaynaklı mezenkimal kök hücreler.

Article History: Received: Dec 06, 2017; Revised: Jan 02, 2017; Accepted: Feb 08, 2017; Available Online: Feb 20, 2018.

DOI: $10.15671 /$ HJBC.2018.220

Correspondence to: Y.E. Arslan, Department of Bioengineering, Eng. Faculty, Çanakkale Onsekiz Mart Univ., Canakkale, Turkey. 


\section{INTRODUCTION}

lants have been used from ancient times until today due to their bioactive substances for the treatment of diseases and/or other medical purposes in traditional medicine. Nowadays, plants are still a prominent option in modern medicine, pharmaceutical chemistry and chemical entities for generating synthetic drugs. Researches on significant biomolecule extraction from medicinal plants have become more notable with an increase in novel methods or technologies such as maceration and Soxhlet extraction presenting opportunities to obtain desired compounds $[1,2]$. Melia azedarach is an evergreen tree and the species of deciduous tree in the mahogany family found mostly in Indian sub-continent [3]. These plants constitute approximately 45 genera and 750 species [4]. The origin of $M$. azedarach is Northern India and China, but today, it can be grown in a few more continents. These trees were previously used for timber and ornamental purposes, until the presence of several cytotoxic and bioactive components was discovered [5].

In recent years, research has revealed this plant to contain excessive amounts of biological active agents such as antioxidants and phenolic components [3]. Because of its extraordinary cytotoxic and antimicrobial activity, M. azedarach has been investigated for its use as an anti-tumor agent, pesticide, for skin disease, viral infections, arthritis, inflammation and analgesic $[6,7]$. The effective results have been obtained when this plant was used as an anti-ulcer, anti-malarial, antiprotozoal, anthelmintic and wound healing agent. In addition to these, Asokan et al. (2015) reported its effect in reducing blood sugar levels [8], and Sultana et al. (2014) exhibited its reducing effect on the urinary calcium, oxalate and phosphate levels [9].

Human mesenchymal stem cells (hMSCs) have been considered as a potential source for cell therapeutics in incurable diseases. hMSCs revitalize regeneration and manage inflammation due to their self-renewal and multi-lineage differentiation features, making them an attractive source in tissue engineering and regenerative medicine. hMSCs can be isolated from a variety of sources such as bone marrow, dental pulp, adipose tissues, placenta, amniotic fluid, tendons, the umbilical cord, etc. Due to their therapeutic nature, these cells are capable of healing various clinically significant diseases [10-14]. In the current study, we prepared aqueous extracts of $M$. azedarach $L$. leaves and green fruit. Chemical composition of extracts was characterized by GC-MS, whereas the total phenolic compound and anti-oxidant activities were determined via spectrophotometric techniques. Cytotoxicity levels of the extracts were examined with the XTT assay. Human adipose-derived MSCs (hAMSCs) were then treated with these aqueous extracts. The aim of this study was to investigate and determine the effects of the cytotoxicity levels of the extracts on hAMSCs. We believe that this pioneering study will open a pathway for promising new studies in tissue engineering and regenerative medicine applications.

\section{MATERIALS and METHODS}

\section{Plant Collection}

M. azedarach L. leaves and green fruit were collected in April from Canakkale, Turkey. Fresh leaves and green fruits were rinsed with distilled water. Then, they were evenly spread and dried in an incubator (Memmert, UN55, Germany) for $24 \mathrm{~h}$. The outer layer of the dried fruit was removed before the extraction process. The dried material was separately homogenized (IKA, T-18 Basic UItra TURRAX, Germany) in order to obtain their powder form.

\section{Extraction of M. azedarach L.}

The extraction process was performed with two different groups. The dried samples were first dissolved in Milli-Q water (Merck-Millipore, Direct-Q3 UV, Germany) at a ratio of $2 \%(\mathrm{w} / \mathrm{v})$. Group-I samples were extracted at $80^{\circ} \mathrm{C}$ for $2 \mathrm{~h}$ with a Soxhlet apparatus (Buchi, Rotavapor R210, Switzerland) (also named the infusion method). The extract was then centrifuged at $6000 \mathrm{rpm}$ for 10 minutes (Hettich, Mikro 120, Germany) and filtered (Macherey-Nagel, MN-615, Germany) under reduced pressure (Buchi, Vacuum pump V-700, Switzerland).

Group-II samples in suspension form were subjected to continuous stirring (also named the ro- 


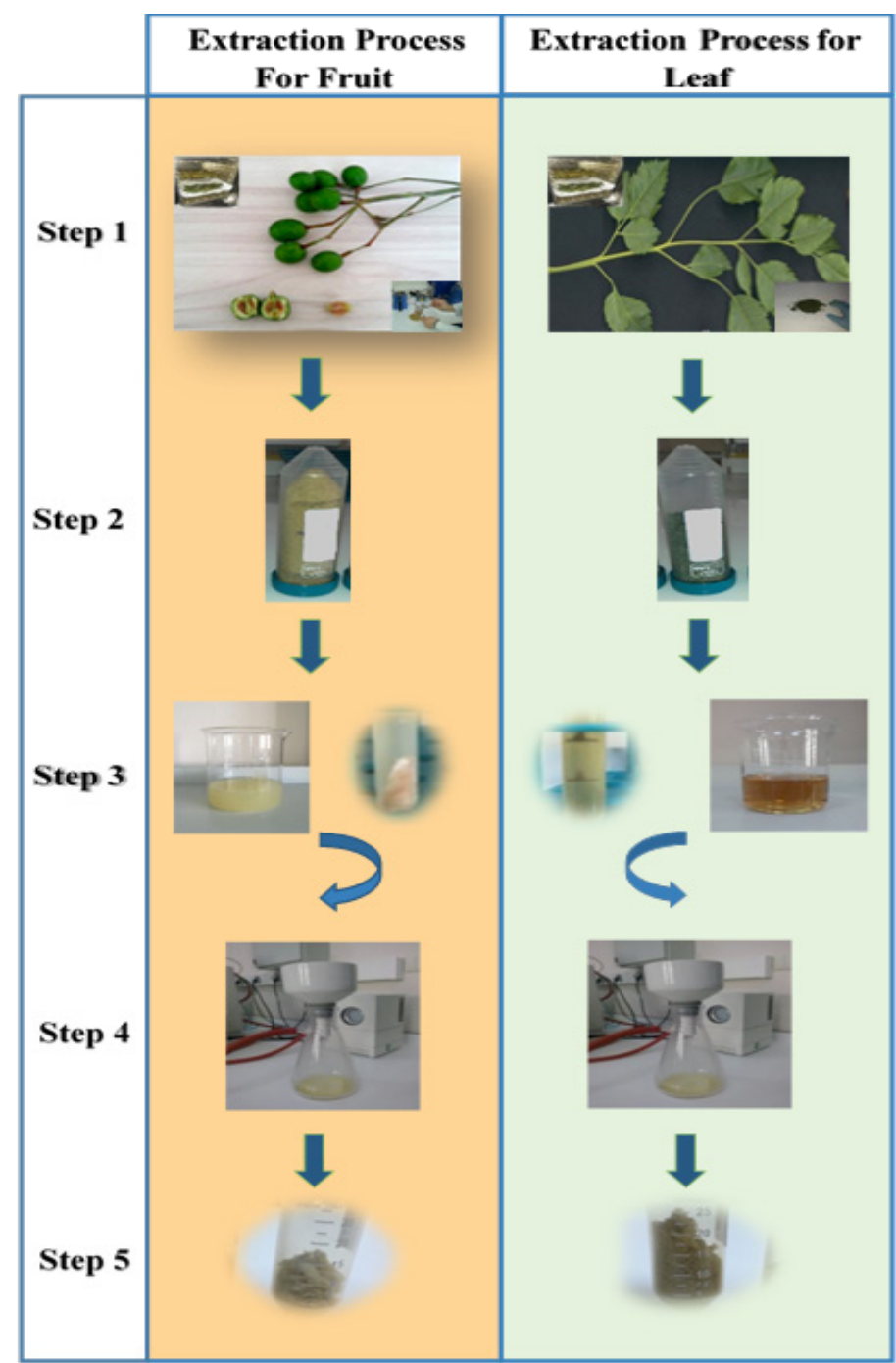

Figure 1. An overview of the extraction processes of $M$. azedarach L. green fruit and leaf. Step 1: Green fruit and leaf were harvested and dried in incubator. Step 2: Green fruit and leaf were homogenized. Step 3: Green fruit and leaf extracts were obtained according to infusion method (Group I) and centrifuged to eliminate the insoluble substances. Step 4: Green fruit and leaf extracts were filtered by vacuum under reduced pressure. Step 5: Fruit and leaf extracts were lyophilized to obtain their water-soluble powder form.

tating method) at room temperature for $72 \mathrm{~h}$. The solutions were then centrifuged at $6000 \mathrm{rpm}$ for 10 minutes and the resulting suspension filtered using filter paper under reduced pressure. The extracts were evaporated under reduced pressure at $80^{\circ} \mathrm{C}$ to concentrate the solution and stored at $-26^{\circ} \mathrm{C}$ for overnight before the lyophilization process. Lyophilization procedure was conducted for overnight (Telstar, LyoQuest, Spain) and the Iyophilized extracts were stored at $-26^{\circ} \mathrm{C}$ for further use. All processes were summarized in Figure 1.

\section{Determination of Total Phenolic Content}

The total phenolic content (TPCS) was spectrophotometrically determined using the Folin Ciocalteu reagent [15]. Dried specimens of the leaf and green fruit extracts were dissolved in Milli- $Q$ water at a ratio of $1 \%(\mathrm{w} / \mathrm{v})$. Briefly, $10 \mathrm{mg}$ of the sample was suspended in 1 of $\mathrm{mL}$ Milli-Q water at room temperature. Then, $900 \mu \mathrm{L}$ of Milli-Q water, $5 \mathrm{~mL}$ of the Folin reagent $(0.2 \mathrm{~N})$ and $4 \mathrm{~mL}$ of sodium carbonate solution $(7.5 \%, \mathrm{w} / \mathrm{v})$ were added into each $100 \mu \mathrm{L}$ sample. The solutions were rested for $2 \mathrm{~h}$ at room temperature in the dark. The absorbance was measured at $765 \mathrm{~nm}$ against a blank solution (Shimadzu UV-mini 1240, Japan). The phenolic content was calculated in terms of Gallic acid (GA) and the results were given as the $\mathrm{GA}$ equivalent (GAE) in terms of $\mathrm{mg} / \mathrm{g}$ dry sample. All chemicals were purchased from Sigma-Aldrich (Germany) unless otherwise specified. 


\section{Determination of the CUPRAC Antioxidant Capacities of the Extracts}

To analyze the antioxidant values of the extracts, the CUPRAC test was applied. Briefly, $20 \mu \mathrm{L}$ of each sample was suspended in $1 \mathrm{~mL}$ of $\mathrm{CuCl}_{2} \cdot 2 \mathrm{H}_{2} \mathrm{O}$ (0.01M, prepared in Milli-Q water), $1 \mathrm{~mL}$ of Neocuproine $\left(7.5 \times 10^{-3} \mathrm{M}\right.$, prepared in Ethanol), 1 $\mathrm{mL}$ of ammonium acetate solution $(\mathrm{pH}=7.0$, in Tris-buffer) and $1.08 \mathrm{~mL}$ of Milli-Q water. After the solutions were incubated in the dark for 30 minutes at room temperature, the absorbance was measured at $450 \mathrm{~nm}$ against a blank solution.

\section{Gas chromatography/Mass Spectrometry Analysis}

M. azedarach L. leaf and fruit powders were dissolved in Milli-Q water and filtered through a $0.45 \mu \mathrm{m}$ sterile filter. GC-MS analysis was performed using a Thermo MS Finnigan Trace DSQ instrument, with a DB-WAX $(30 \mathrm{~m} \times 0.25 \mathrm{~mm}$ i.d.; film thickness $0.25 \mu \mathrm{m}$ ) column. The $\mathrm{GC}$ oven temperature was programmed in the following manner; $50^{\circ} \mathrm{C}$ for 1 minute, followed by an increase rate of $3^{\circ} \mathrm{C} /$ minute up to $220^{\circ} \mathrm{C}$. Helium was used as the carrier gas at a flow rate of $1 \mathrm{ml} /$ minute. All data were processed using the Xcalibur software.

\section{Cell Culture Experiment}

Human adipose mesenchymal stem cells (hAMSCs) (Merck-Millipore, human adipose mesenchymal stem cell kit, cat. no. ScC038 and lot no. QVP1303200, USA) were expanded, and their multipotency capacities validated according to a previously reported method $[16,17]$. Passages between 2 and 5 were utilized for all experiments. hAMSCs were seeded on 96-well plates with a density of $1 \times 10^{4}$ cells/well, and incubated at $37^{\circ} \mathrm{C}$, under $5 \% \mathrm{CO}_{2}$ and $95 \%$ relative humidity conditions (Panasonic, Japan) for $24 \mathrm{~h}$. Aqueous extracts of M. azedarach L. at various concentrations to the hAMSCs. Briefly, the extracts were added into mesenchymal stem cell medium at different ratios depending on its nature; $150,600,900,1500$ and $2100 \mu \mathrm{g} /$ well for that of the fruit, and 100, 200, 400 and $600 \mu \mathrm{g} /$ well for that of the leaf.

\section{Measuring Cell Viability}

Cytotoxicity of the extracts were assessed using commercially available the XTT assay kit (Biological Industry, USA). In brief, hAMSCs were seeded in 96-well plates and incubated for $24 \mathrm{~h}$ ensuring they reached $85-90 \%$ confluence. The stem cells were then treated with green fruit and leaf extracts $24 \mathrm{~h}$ under conventional culture conditions. Subsequently, the XTT activation reagent was added into each well and incubated for a further $4 \mathrm{~h}$. The absorbances were then measured at wavelength range of 450-500 nm against the control group $(n=3)$ with a microplate reader (Thermo-Scientific, Multiskan ${ }^{\mathrm{TM}} \mathrm{GO}$ ).

\section{RESULTS and DISCUSSIONS}

\section{Determination of the Success of Extraction Process}

The yield percentage of the green fruit and leaf extracts were calculated using the equation given below. The infusion technique produced extraction yields of $24.11 \%$ and $37.98 \%$ for the green fruit and leaf respectively, whereas $17.76 \%$ and $27.00 \%$ were obtained through the rotation process.

The infusion extraction yields were significantly higher than those of rotation extract yields. Similar results have been obtained in literature [18].

\section{Assessment of the Total Phenolic Contents of Extracts}

TPCs of the green fruit and leaf extracts were found to be 173.67 and $312.33 \mathrm{mg} \mathrm{GAE} / \mathrm{g}$ dry weight, respectively. The data clearly outlines that leaf extracts contain a richer phenolic content (Figure 2A) with respect to that of the fruit extract resulting in high free radicalsweeping and antioxidant activities [19]. Phenolic compounds are one of the major secondary

SampleYield $=\left[\frac{(\text { Initial (dry })) \text { Weight }- \text { LyophilizedWeight }}{\text { Initial }(\text { dry }) \text { Weight }}\right] x 100$

metabolite classes of plants which possess a wide range of biological effects including antioxidant activity, antimutagenicity, anti-carcinogenicity, etc. [20]. In a similar study, M. azedarach L. was extracted using various organic solvents in order to investigate the potential antifeedant activities of its biological contents [5].

In a study, aqueous extracts of $M$. azedarach L. green and ripe fruit were prepared, where the phenolic content was found to be $10.54 \mathrm{mg}$ 

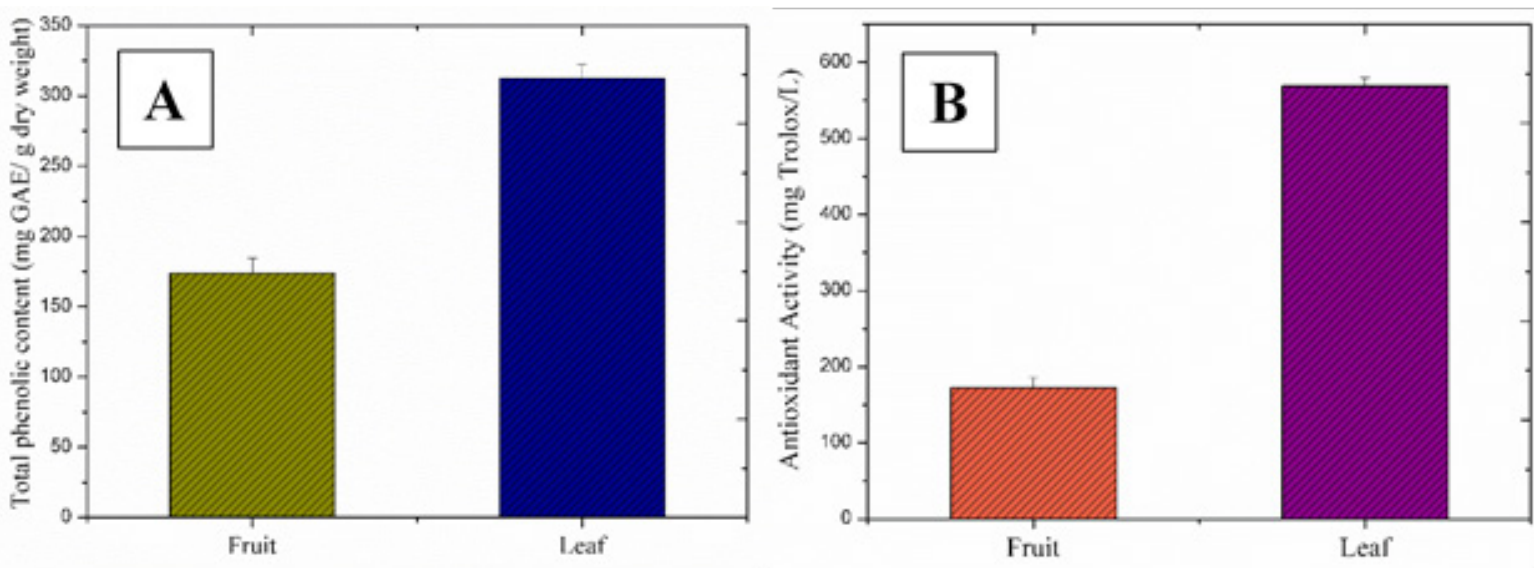

Figure 2. Total phenolic contents (A) and antioxidant activities (B) of green fruit and leaf extracts.

GAEs/g dry weight [4]. In our study, TPC of green fruit was found as $173.67 \pm 10.84 \mathrm{mg} \mathrm{GAEs} / \mathrm{g}$ dry weight according to the infusion method which reveals the importance of the temperature during the extraction process. It should not be forgotten that a number of factors (collection time, geographical origin, climatic conditions, etc.) also have influence on the phenolic compound content in a plant extract [4].

\section{CUPRAC Antioxidant Capacity}

The CUPRAC method is based on the $\mathrm{Cu}(\mathrm{II})-\mathrm{Cu}$ (I) reduction by antioxidants in the presence of neocuproine. It is important that CUPRAC reagent should be freshly prepared $[21,22]$ it is desirable to establish a method that can measure the total antioxidant activity level directly from vegetable extracts. The current literature clearly states that there is no \"total antioxidantl" as a nutritional index available for food labeling because of the lack of standard quantitation methods. Thus, this work reports the development of a simple, widely applicable antioxidant capacity index for dietary polyphenols and vitamins $C$ and $E$, utilizing the copper(II. In our study, the antioxidant content of the leaf and green fruit extracts were determined by the CUPRAC method, which showed leaf extracts to have the maximum antioxidant activity according to Trolox calculations.

As shown in Figure 2B, the leaf and green fruit extracts exhibit strong antioxidant activity. Cupric reducing capacity of the aqueous green fruit and leaf extracts were found to be $172.51 \pm 13.23$ and $569.16 \pm 10.41 \mathrm{mg}$ Trolox/L, respectively. Aoudia et al. (2013), found the cupric reducing capacity of aqueous leaf extracts to be $78.71 \mathrm{mg}$ Trolox/L which underlines the success of infusion process seed and almonds of Melia azedarach grown in Algeria were defatted and extracted with three solvents, aqueous $70 \%$, v/v [23].

\section{GC-MS Results}

In order to identify the chemical composition of the leaf and green fruit extracts, GC-MS, a very widespread analytical technique, was performed. According to the results, stearic acid, polyunsaturated fatty acid, furfural, 2-furancarboxyaldehyde-5-(methyl), acetic acid, 5-hydroxymethyl-2-furaldehyde, hexanoic acid, monoterpenes, phytosterol, flavonoids, 2,3-Dihydro3,5-Dihyroxy-6-Methyl-4H-Pyran-4-One and ethyl nonadecanoate were determined in the green fruit extract (Figure 3A). The leaf extract on the other hand revealed the presence of flavonoids, furfural, 2-furancarboxyaldehyde-5-(methyl), acetic acid, 5-Hydroxymethyl-2-furaldehyde, hexanoic acid, phytosterol, monoterpenes, Vitamin $\mathrm{E}$ and 2,3-Dihydro-3,5-Dihyroxy-6-Methyl-4H-Pyran-4One (Figure 3B). GC-MS screening showed that the most abundant substance (\%) was acetic acid according to the peak area.

Organic acids and furfural derivatives have been used against plant parasitic nematodes, for years. On the other hand, flavonoid derivatives are potential chemical substances used as antiinflammatory and anti-cancer agents. Additionally, vitamin $\mathrm{E}$ is an antioxidant and it protects tissues from deleterious free radicals. Apart from these, 


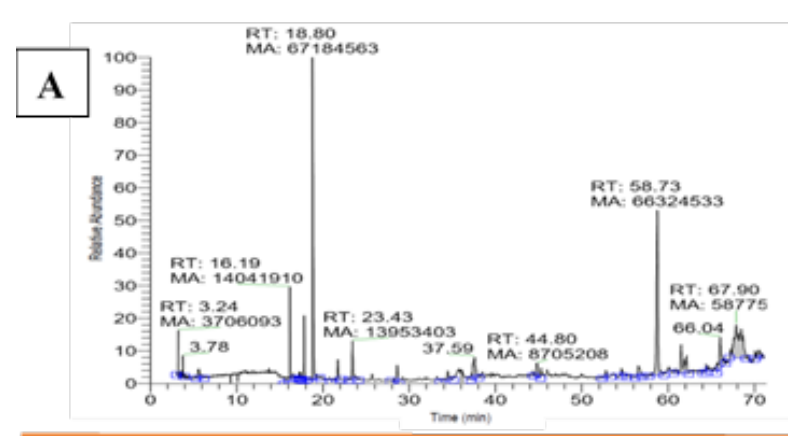

\begin{tabular}{|c|c|c|c|}
\hline RT & M.wi & M.F. & Compoend Same \\
\hline 13,21 & 284 & $\mathrm{C}_{\mathrm{ta}} \mathrm{H}_{2} \mathrm{O}_{2}$ & Stearic aid \\
\hline 13.21 & 294 & $\mathrm{C}_{13} \mathrm{H}_{2} \mathrm{O}_{2}$ & Pobunustuated fatty xid \\
\hline 16.38 & 96 & $\mathrm{C}_{4} \mathrm{H}_{2} \mathrm{O}_{2}$ & Fufiunal \\
\hline 19.53 & 110 & $\mathrm{C}_{2} \mathrm{H}_{4} \mathrm{O}_{2}$ & 2-furanxabtoxyaldetyder.4(medyl) \\
\hline 21.15 & $\infty$ & $\mathrm{C}_{2} \mathrm{H}_{2} \mathrm{O}_{2}$ & Acotic Acid \\
\hline 39.94 & 126 & $\mathrm{C}_{2} \mathrm{H}_{4} \mathrm{O}_{3}$ & 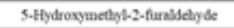 \\
\hline 37.88 & 116 & $\mathrm{C}_{2} \mathrm{H}_{4} \mathrm{O}_{2}$ & Hecunovic axid \\
\hline 37.57 & 152 & $\mathrm{C}_{10} \mathrm{H}_{12} \mathrm{O}$ & Menceterpanes \\
\hline 39,17 & 414 & $\mathrm{C}_{2} \mathrm{H}_{5} \mathrm{O}$ & Paytrowerol \\
\hline 45,31 & 222 & $\mathrm{C}_{12} \mathrm{H}_{2} \mathrm{~N} \mathrm{~N}_{j} \mathrm{O}_{3}$ & Flavoenoids \\
\hline 58.77 & 144 & $\mathrm{C}_{4} \mathrm{H}_{4} \mathrm{O}_{4}$ & 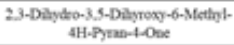 \\
\hline 60.54 & 326 & $\mathrm{C}_{2} \mathrm{H}_{6} \mathrm{O}_{2}$ & Ethyl nonadomante \\
\hline
\end{tabular}

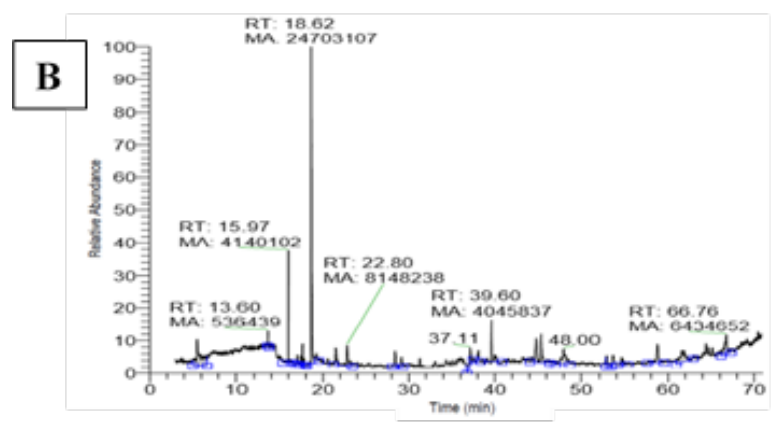

\begin{tabular}{|c|c|c|c|}
\hline RT & s.wt & M.F. & Compoued Name \\
\hline 11.49 & 222 & $\mathrm{C}_{\mathrm{Z}} \mathrm{H}_{4} \mathrm{~N}_{2} \mathrm{O}_{3}$ & Flavonoids \\
\hline 16.38 & 96 & $\mathrm{C}_{3} \mathrm{H}_{2} \mathrm{O}_{2}$ & Fufural \\
\hline 19.53 & 110 & $\mathrm{C}_{4} \mathrm{H}_{4} \mathrm{O}_{2}$ & 2-firnocatboxyaldetyde-5-(methyl) \\
\hline 21.15 & 60 & $\mathrm{C}_{2} \mathrm{H}_{4} \mathrm{O}_{2}$ & Acotic Acid \\
\hline 39,94 & 126 & $\mathrm{C}_{9} \mathrm{H}_{4} \mathrm{O}_{3}$ & S-Hydoxymedyh-2.funalechyde \\
\hline 37,88 & 116 & $\mathrm{C}_{4} \mathrm{H}_{1} \mathrm{O}_{2}$ & Heunobs acid \\
\hline 40.25 & 414 & $\mathrm{C}_{2} \mathrm{H}_{4} \mathrm{O}$ & Paytosterol \\
\hline 42.61 & 412 & $\mathrm{C}_{2} \mathrm{H}_{4} \mathrm{O}$ & Phytosterol \\
\hline 45.61 & 152 & $\mathrm{C}_{16} \mathrm{H}_{4} \mathrm{O}$ & Moncterpenes \\
\hline 56.35 & 536 & $\mathrm{C}_{2} \mathrm{H}_{30}$ & Vitamin E \\
\hline$\$ 8.77$ & 144 & $\mathrm{C}_{2} \mathrm{H}_{4} \mathrm{O}_{4}$ & 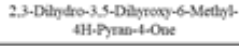 \\
\hline
\end{tabular}

Figure 3. GC-MS chromatograms of green fruit (A) and leaf (B) extracts.
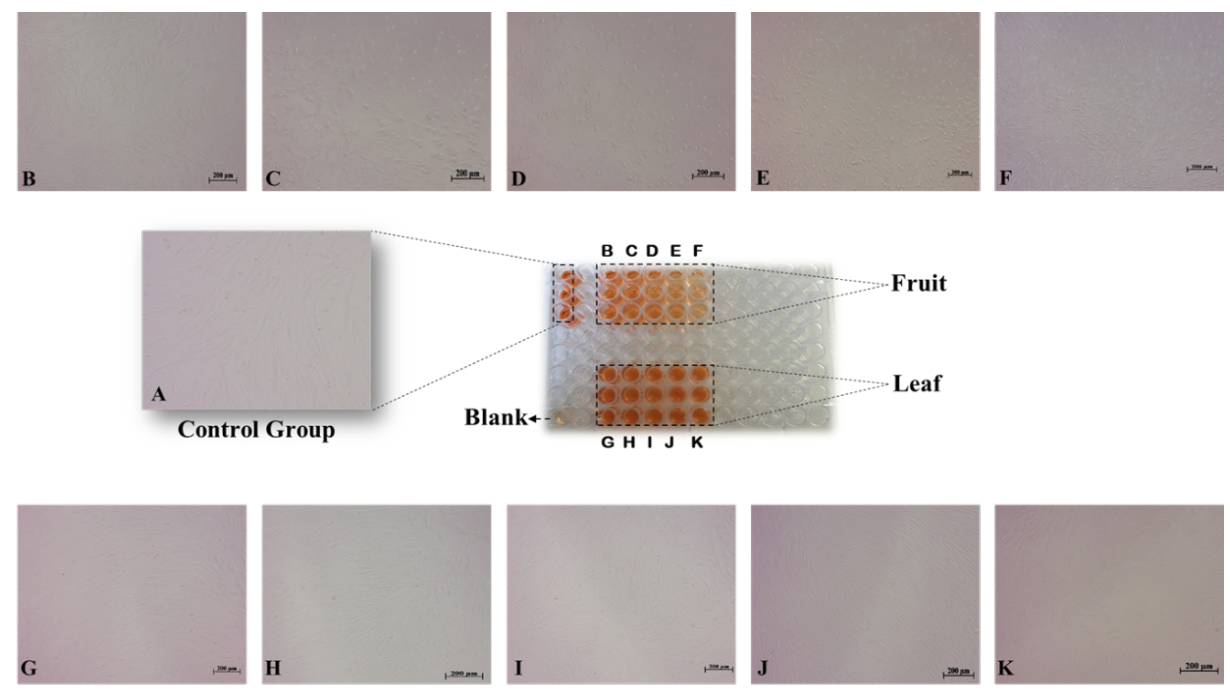

Figure 4. Experimental setup for XTT assay and inverted phase-contrast microscopy images of hAMSCs that were treated with various concentrations of the extracts. Un-treated hAMSCs as control (A), microscopic images of green fruit extract ( $B, C, D, E$ and $F)$ and leaf extract $(G, H, I, J$ and $K$ ) as dose-depended concentrations (Black scale bar: $200 \mu \mathrm{m})$.

monoterpenes can inhibit microbial proliferation and prevent dehydration, etc. [24,25]. Finally, the active substance/s that cause cell apoptosis were not specified because of the huge chemical composition of the green fruit extract.

\section{Cytotoxicity}

Human adipose-derived MSCs were treated with aqueous leaf and green fruit extracts, and the cell viability was determined via the XTT assay often used in the identification of cytotoxicity levels (Figure 4). The colorimetric assay depends on the reduction of tetrazolium salts (XTT) to orange colored formazan products by living cells (metabolically active). Cell viability measurements obtained from the XTT assay are represented in Figure 5.

M. azedarach L. green fruit extracts showed dose dependent cytotoxic effect on hAMSCs. The $\mathrm{IC}_{50}$ value for green fruit extract was found to be $728.05 \mu \mathrm{g} /$ well, whereas no value could be determined for the leaf extract because it did not show any cytotoxic effect against the 

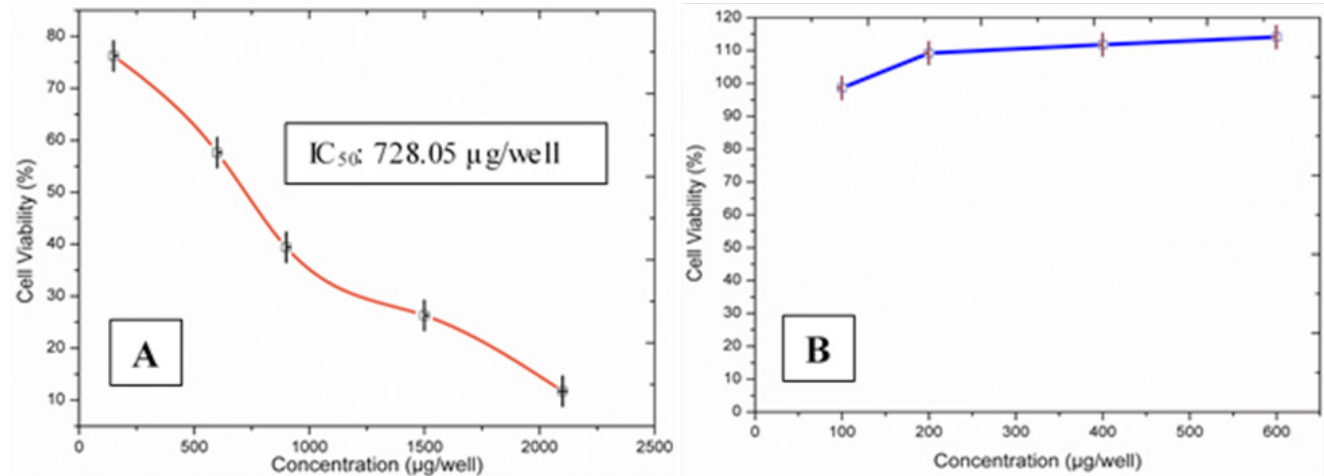

Figure 5. Cell viability assessment of green fruit (A) and leaf (B) extract.

hAMSCs. Green fruit extracts inhibited the cell proliferation as shown in Figure 5A. Although the TPC and antioxidant capacities of leaf extracts were higher than that of the green fruit extract (Figure 2), surprisingly, the green fruit extract showed a remarkable cytotoxic effect on hAMSCs in contrast to leaf extract (Figure 5B). The absence of similar studies in the literature limits our interpretation about these results. It is noteworthy in mentioning that the underlying reason of cytotoxicity is not related to the TPC or antioxidant capacity, but probably, to the presence of a chemical compound.

\section{CONCLUSION}

Plants have been used as alternative medicine for therapeutic purposes since the beginning of mankind. Therefore, the identification of extraordinary chemical contents is crucial for their use in the healthcare industry. Nowadays, hMSCs, hAMSCs in particular, are utilized in the treatment of many types of diseases. Exploring novel agents or substances from medicinal plants for proliferation, differentiation or maintenance of hMSCs may present and lead to new opportunities in tissue engineering and regenerative medicine applications. M. azedarach L. leaf and green fruit extracts were prepared and applied to hAMSCs with the aim of evaluating their cytotoxicity levels, which in turn is the preliminary phase in understanding the potential effect of these extracts on hAMSCS.

The green fruit extract was found to be highly cytotoxic in contrast to leaf extract. We believe further studies on M. azedarach L. extracts should be designed in order to gain a better understanding of the main underlying causes of the cytotoxicity or proliferation of hAMSCs.

\section{Conflict of interest}

The authors declare that they have no conflict of interest.

\section{Acknowledgements}

The authors acknowledge the financial support of the Çanakkale Onsekiz Mart University, Scientific Research Projects Coordination Unit (Project ID. FBA-2015-549). We would also like to thank the Çanakkale Onsekiz Mart University, Science and Technology Application \& Research Center for their support regarding the GC-MS analyses. Finally, we would like to thank Prof. Kaan C. Emregul for his comments and language proofreading.

\section{References}

1. S.S. Handa, S.P.S. Khanuja, G. Longo, D.D. Rakesh, Extraction technologies for medicinal and aromatic plants, J. Nat. Prod., 5 (2008) 440.

2. B. Biswas, K. Rogers, F. Mclaughlin, D. Daniels, A. Yadav, Antimicrobial activities of leaf extracts of guava (Psidium guajava I.) on two gram-negative and gram-positive bacteria, Int. J. Microbiol., (2013) 1-6.

3. M. Azam, A. Mamun-Or-Rashid, N. Towfique, M. Sen, S. Nasrin, Pharmacological potentials of Melia azedarach L., A review, Am. J. Biosci., 1 (2013) 44-49.

4. I. Khan, M. Yasinzai, Z. Mehmood, I. Ilahi, Comparative study of green fruit extract of Melia azedarach linn. with its ripe fruit extract for antileishmanial, larvicidal, antioxidant and cytotoxic activity, Asian J. Nat. Appl. Sci., 2 (2014) 442-454.

5. C. Carpinella, C. Ferrayoli, G. Valladares, M. Defago, S. Palacios, Potent limonoid insect antifeedant from Melia azedarach, Biosci. Biotechnol. Biochem., 66 (2002) 1731-1736.

6. T. Akihisa, X. Pan, Y. Nakamura, T. Kikuchi, N. Takahashi, M. Matsumoto, E. Ogihara, M. Fukatsu, K. Koike, H. Tokuda, Limonoids from the fruits of Melia azedarach and their cytotoxic activities, Phytochemistry, 89 (2013) 59-70. 
7. K. Sangeetha, S. Rajarajan, In vitro antiviral activity of indian medicinal plants to asian and east central south african lineage of Chikungunya virus, Int. J. Pharm. Sci. Res., 6 (2015) 692-697.

8. B. Asokan, B. Rajkumar, S. Balamuruganvelu, S. Jaikumar, In vivo antidiabetic activity of ethanolic flower extract Melia azedarach L., Acta Biomed. Sci. 2 (2015) 215-217.

9. S. Sultana, H.M. Asif, N. Akhtar, M. Waqas, S.U. Rehman, Comprehensive review on ethanobotanical uses, phytochemistry and pharmacological properties of Melia azedarach linn., Asian J. Pharm. Res Heal. Care, 6 (2014) 26-32.

10. J. Yu, Y. Wang, Z. Deng, L. Tang, Y. Li, J. Shi, Y. Jin, Odontogenic capability: bone marrow stromal stem cells versus dental pulp stem cells, Biol. Cell, 99 (2007) 465-474.

11. H. Jin, Y. Bae, M. Kim, S.-J. Kwon, H. Jeon, S. Choi, S. Kim, Y. Yang, W. Oh, J. Chang, Comparative analysis of human mesenchymal stem cells from bone marrow, adipose tissue, and umbilical cord blood as sources of cell therapy, Int. J. Mol. Sci., 14 (2013) 17986-18001.

12. Y.E. Arslan, M.M. Hız, T. Sezgin Arslan, The use of decellularized animal tissues in regenerative therapies, Kafkas Univ. Vet. Fak. Derg., 21 (2015) 139145.

13. I. Jun, Y. Bin Lee, Y.S. Choi, A.J. Engler, H. Park, H. Shin, Transfer stamping of human mesenchymal stem cell patches using thermally expandable hydrogels with tunable cell-adhesive properties, Biomaterials, 54 (2015) 44-54.

14. M.T. Sutton, D. Fletcher, S.K. Ghosh, A. Weinberg, R. van Heeckeren, S. Kaur, Z. Sadeghi, A. Hijaz, J. Reese, H.M. Jane, D.P. Lennon, A.I. Caplan, T.L. Bonfield, Antimicrobial properties of mesenchymal stem cells: therapeutic potential for cystic fibrosis infection, and treatment., Stem Cells Int., 2016 (2016) 1-12.

15. V.L. Singleton, J.A. Rossi, J. Jr, Colorimetry of total phenolics with acid reagents, Am. J. Enol. Vitic., 16 (1965) 144-158.

16. E. Erten, T. Arslan Sezgin, B. Derkus, Y.E. Arslan, Detergent-free decellularization of bovine costal cartilage for chondrogenic differentiation of human adipose mesenchymal stem cells in vitro, RSC Adv., 6 (2016) 94236-94246.
17. Y.E. Arslan, T. Sezgin Arslan, B. Derkus, E. Emregul, K.C. Emregul, Fabrication of human hair keratin/ jellyfish collagen/eggshell-derived hydroxyapatite osteoinductive biocomposite scaffolds for bone tissue engineering: From waste to regenerative medicine products, Coll. Surf. B Biointerf., 154 (2017) 160-170.

18. A.V. Khân, A.A. Khan, I. Shukla, In vitro antibacterial potential of Melia azedarach crude leaf extracts against some human pathogenic bacterial strains, Ethnobot. Leafl., 12 (2008) 439-445.

19. J. Kubola, S. Siriamornpun, Phenolic contents and antioxidant activities of bitter gourd (Momordica charantia L.) leaf, stem and fruit fraction extracts in vitro, Food Chem., 110 (2008) 881-890.

20. G. Zengin, C. Sarikurkcu, P. Uyar, A. Aktumsek, S. Uysal, M.S. Kocak, R. Ceylan, Crepis foetida L. subsp. rhoeadifolia (Bieb.) Celak. as a source of multifunctional agents: Cytotoxic and phytochemical evaluation, J. Funct. Foods, 17 (2015) 698-708.

21. R. Apak, K. Güçlü, M. Özyürek, S.E. Karademir, Novel total antioxidant capacity index for dietary polyphenols and vitamins $C$ and $E$, using their cupric ion reducing capability in the presence of neocuproine: CUPRAC Method, J. Agric. Food Chem., 52 (2004) 7970-7981.

22. S.D. Çekiç, K.S. Başkan, E. Tütem, R. Apak, Modified cupric reducing antioxidant capacity (CUPRAC) assay for measuring the antioxidant capacities of thiolcontaining proteins in admixture with polyphenols, Talanta, 79 (2009) 344-351.

23. H. Aoudia, B.D. Oomah, F. Zaidi, R. Zaidi-Yahiaoui, J.C.G. Drover, J.E. Harrison, Phenolics, antioxidant and anti-inflammatory activities of Melia azedarach extracts, Int. J. Appl. Res. Nat. Prod., 6 (2013) 19-29.

24. N.G. Ntalli, S. Vargiu, U. Menkissoglu-Spiroudi, P. Caboni, Nematicidal carboxylic acids and aldehydes from Melia azedarach fruits, J. Agric. Food Chem., 58 (2010) 11390-11394.

25. A. Sen, A. Batra, Chemical composition of methanol extract of the leaves of Melia azedarach L., Asian J. Pharm. Clin. Res., 5 (2012) 42-45. 